\title{
Recent Views on the Biosynthesis of the Plant Starch Granule
}

\author{
植物澱粉粒の生合成についての最近の見解
}

\author{
Ball, Steven G. \\ Laboratoire de Chimie Biologique, Unité Mixte de Recherche du C.N.R.S. ${ }^{\circ} 111$, Université des Sciences et \\ Technologies de Lille 59655 Villeneuve d'Ascq Cedex, France, Fax: 33-20-43-65-55
}

Key Words: amylopectin synthesis, amilose synthesis, starch

\begin{abstract}
Plant starch can be distinguished from bacterial, fungal and animal glycogen by the simultaneous presence of at least 2 distinct fractions (amylose and amylopectin) whose relative arrangement inside a huge insoluble granule remains to be determined. Amylopectin, the major branched fraction is itself a highly organized molecule displaying a succession of clusters of glucans packed in crystal arrays. The unit cluster size $(9 \mathrm{~nm})$ is a remarkably constant feature of all plants examined which in turn suggests the existence of a highly conserved and ordered biosynthetic pathway. This review after giving a brief overview on starch structure and metabolism will focuss on the building of the granule's architecture. The genetic and biochemical evidence summarized here all point to the presence of multiple elongation and branching enzymes who are only partly redundant in function for starch biosynthesis. We suggest that each enzyme is responsible for the building of specific granule substructures.
\end{abstract}

\section{A. Introduction}

Starch accumulates as a complex granular structure made of a glucans ( $\alpha 1,4$-linked and $\alpha 1,6$-branched) both in the leaf cell chloroplast (transient starch) or in the amyloplast of the plant storage tissue cell (storage starch). All published structural characterizations of starches to date deal with storage starch (Fig. 1) and very little remains known about the fine structure and composition of leaf (transient) starch. The storage polysaccharide is usually defined as a mix of 2 distinct fractions : amylopectin and amylose. Amylopectin, the major compound, is composed of intermediate size $\alpha 1$,4-linked glucans (the $\mathrm{A}$ and $\mathrm{B} 1$ chains) that are clustered together and hooked to longer spacer glucans (the B2, B3 and B4 chains) by $\alpha 1,6$ linkages $(1,2)$. Segments of these chains intertwine to form parallel arrays of double helices responsible for the crystallinity of
要 約

植物の澱粉は少なくとも2つの明瞭に区別のできる区分(ア ミロースおよびアミロペクチン)からなっており、それが細菌、 かび、および動物のグリコーゲンと異なる点である。巨大な不 溶性澱粉粒の内部でのこれら2つの区分の相対的な配置はまだ分 かっていない。アミロペクチンは枝分かれ構造をもった主成分 であるが、それ自身、結晶の配列中にグルカンの房状構造(クラ スター)が連続して詰め込まれた形の高度に組織化された分子で ある。その房の大きさ $(9 \mathrm{~nm})$ は研究されたすべての植物において おどろくほど一定であるが、このことは、植物には高度に保存 され、かつ秩序だった生合成経路が存在していることを示唆し ている。この総説では、澱粉の構造と代謝について簡単に振り 返った後、澱粉粒の構造の構築に関して焦点をあててみたい。 ここで要約した遺伝学的および生化学的なすべての証拠は、グ ルカンの伸長と分岐形成に関与する多様な䣼素が存在し、おの おのの酵素の澱粉生合成における役割はほんの部分的にしか重 複していないことを示している。私達はこの総説で、それぞれ の酵素が澱粉粒の特定の基本構造を構築する役割をもっている ことを示唆したい。

\section{A. はじめに}

澱粉は $\alpha$ グルカン $(\alpha 1,4-$ 結合および $\alpha 1,6$-分㞳 $)$ からなる複 雑な構造をもった顆粒として、葉細胞葉緑体(一過性の澱粉、同 化港粉)あるいは植物における貯蔵組織細胞のアミロプラスト(貯 蔵澱粉)に蓄積する。今までに報告された澱粉の構造解析はすべ て貯蔵港粉(図1)について行われたものであり、葉の(同化)澱粉 につてはほとんど分かっていない。この貯蔵多糖は通常2つの明 瞭に区別される区分、即ち、アミロースおよびアミロペクチン の混合物として定義されている。アミロペクチンはその主成分 であり、中間的な長さの $\alpha 1,4-$ 結合からなるグルカン鎖(Aおよび B1鎖)が集合して房状構造を形成し、これらがより長いグルカン 鎖(B2、B3、およびB4鎖)に $\alpha 1$ 1,6-結合によって結合した構造を もつ $(1 、 2)$ ここれらの鎖の一部は織り合わさって二重らせんの平 行配列を形成しており、これが澱粉の結晶性の原因となってい

This work was supported by the Université des Sciences et Technologies de Lille, by the Ministère de l'Education Nationale, by the Centre National de la Recherche Scientifique (Unité Mixte de Recherche du CNRS n ${ }^{\circ} 111$. Director André Verbert) and by a special grant from the starch processing company Roquette Frères (Lestrem-France).

Abbreviations: SSSII, soluble starch synthase II; SSSI, soluble starch synthase I; GBSS, granule-bound starch synthase; BEI, branching enzyme I, BEII, branching enzyme II 

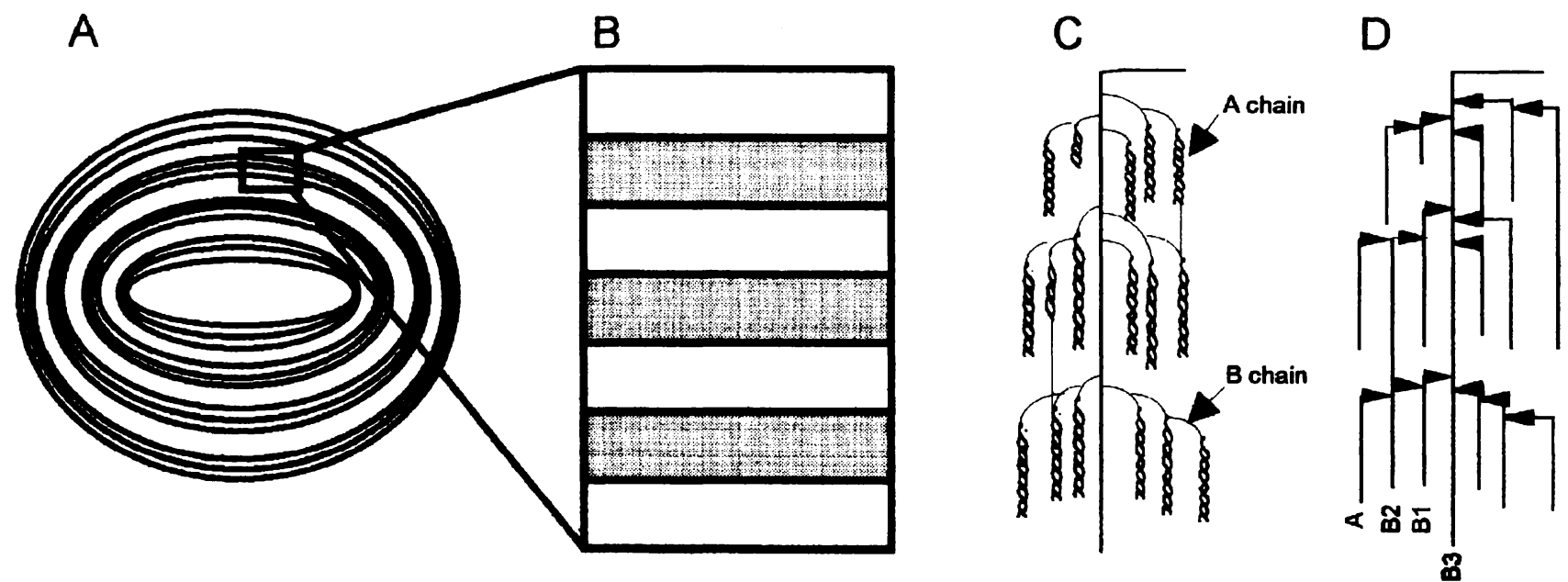

Fig. 1. Starch granule organization and amylopectin primary and secondary structures. (A) Panel A displays a schematic view of the granule with it's succession of amorphous and crystalline growth rings. (B) Panel B relates a section of the granule to the molecular organization of amylopectin (note that the position of amylose is too uncertain to be drawn) shown on the same scale in panels $\mathrm{C}$ and D. (C) Secondary structure of 3 successive amylopectin clusters. (D) Primary structure of 3 successive amylopectin clusters explaining the nomenclature adopted for the different types of chains

starch. Tuber and seed storage starches differ by their crystalline types [for review see (3)]. The A-type is characteristic of all cereal starches while the B-type can be found in potato tubers and high amylose mutant maize starch. The exact conservation in the case of storage starch of the amylopectin cluster size $(9 \mathrm{~nm})$ throughout the plant kingdom (4) suggests the existence of a highly ordered, precise and well conserved biosynthetic pathway. Amylose is often referred to as a smaller linear molecule with very few $\alpha 1,6$ branches whose association with amylopectin inside the granule remains to be determined. In this review, we will focuss our attention on the building of the starch structure itself and will deal only very briefly with the supply of the nucleotide-sugar precursor. In fact, we believe that the supply of ADP-glucose can to some extent regulate the composition and structure of starch.

\section{B. The Supply of ADP-glucose}

There is an overwhelming body of evidence pointing to ADP-glucose as the sole precursor for starch synthesis in plants. The discovery was initially made by Leloir $(5,6)$ who realized that ADP-glucose was favored over UDP-glucose by the starch synthases for incorporation into glucans. Since these initial observations, the enzyme responsible for the synthesis of ADP-glucose from Glc-1-P and ATP (ADP-glucose pyrophosphorylase) has been purified to homogeneity in many different organisms [(7), for review see (8)]. It was shown to be a heterotetramer enzyme composed of 2 large and small subunits of about 50 to $55 \mathrm{kDa}(8)$. The enzyme is subject to allosteric interactions. 3-Phosphoglycerate is the most potent activator while orthophosphate modulates the activity negatively.
る。塊茎および種子の貯蔵澱粉はそれらの結晶形において異 なっている[総説としては(3)]。A夕イプの結晶型はすべての種子 澱粉にみられ、一方Bタイプはジャガイモ塊茎およびトウモロコ シの高アミロース変異体にみられる。貯蔵澱粉のアミロペクチ ンの房状構造の大きさ $(9 \mathrm{~nm})$ が植物界を通して正確に保存されて いる(4)ことから、高度に秩序だった、精密かつ良く保存された 生合成経路の存在が示唆される。アミロースはしばしば、非常 に少数の $\alpha 1,6$ 分岐をもつアミロペクチンより低分子の直鎖状分 子といわれるが、澱粉粒内でアミロペクチンとどのような関係 で存在しているかはよく分かっていない。この総説では、澱粉 の構造自体の構築に焦点を絞ることとし、糖ヌクレオチド前駆 体の供給についてはごく簡単に触れることとする。実際、私達 はADP-グルコースの供給が澱粉の構造や組成をある程度制御し ていると信じている。

\section{B. ADP-グルコースの供給}

植物においてADP-グルコースが澱粉生合成の唯一の前駆体 であることを示す証拠は圧倒的に存在する。このことはLeloir (5、6)によって初めて発見されたが、このとき彼は澱粉生合成の 際のグルカンへの取り込みが、ADP-グルコースの方がUDP-グ ルコースよりも高いことに気がついた。これらの最初の報告の 後に、グルコース-1ーリン酸およびATPからADP-グルコースを合 成する酵素(ADP-グルコースピロホスホリラーゼ)が多くの異 なった生物から精製された[(7)、総説としては(8)]。この酵素は大 小2種のサブユニット(およそ50から55 kDa)からなる4量体の酵素 であることが示された $(8)$ 。この酵素はアロステリック制御を受 ける。3-ホスホグリセリン酸は最も効果のある活性化肪であ り、正リン酸は負の制御を行う。この制御は澱粉合成と葉緑体 
This regulation not only tightly couples starch synthesis to photosynthesis in the chloroplast but also seems to be at work in the amyloplast for storage starch synthesis. That ADP-glucose pyrophosphorylase is the mandatory rate-limiting step for starch biosynthesis has received considerable support from genetic and molecular biological studies. Mutants with reduced enzyme activity in maize (9), pea (10) and Arabidopsis (11) have correspondingly reduced rates of starch biosynthesis and starch content. In potato the expression of antisense RNAs directed against one of the enzyme subunits leads to a proportional decrease in enzyme activity and starch content (12). In Arabidopsis mutants have been obtained that completely lack both enzyme activity and starch (13). Similar mutants have very recently been obtained in the unicellular green alga Chlamydomonas reinhardtii. Moreover in Chlamydomonas mutants have been obtained that displayed reduced sensitivity to 3-PGA activation (14). These mutants, while having wildtype levels and kinetics of the unactivated enzyme, displayed a 90\% drop in starch content in all conditions tested. Conversely, transgenes from mutant bacteria coding for a high specific activity enzyme were overexpressed in potato tubers and yielded a 30 to $60 \%$ increase in starch content (15). The involvement of a plastidic form of phosphoglucomutase for the supply of Glc1-P to the leaf chloroplast has also been confirmed by mutant isolation in Arabidopsis thaliana (16) and Nicotiana sylvestris (17). Interestingly despite intensive investigations no such mutant has ever been reported in maize or other starch accumulating crops. This is suggestive evidence for the import of Glc1-P into the amyloplast. In fact conclusive biochemical evidence for hexose transport (both Glc-1-P and Glc-6-P) has been obtained initially from maize and wheat (18) and since then in other starch storing crops $(19,20)$. Thus it would be very tempting to speculate that in leaves starch synthesis would rely on the flow of carbon from the Calvin cycle to Glc-6-P and its subsequent conversion to Glc-1-P by plastidic phosphoglucomutase while in non-photosynthetic amyloplasts hexose-phosphates including Glc-1-P would be massively imported. The ATP needed for synthesis of ADP-glucose stems from photophosphorylation in the chloroplast. In the non photosynthetic storage tissues, ATP is probably imported into the amyloplast through an adenylate translocator such as that coded by the maize $B T 1$ gene (21). Other issues such as the existence of an alternate pathway for starch synthesis in maize or the likely cytosolic localization of one specific isoform of ADP-glucose pyrophosphorylase in barley or wheat endosperms are still controversial and will not be dealt with here. In any case, whether it be in an alternate or classical pathway, we will end up with ADP-glucose in the plastid as the sole glucose donor for the biosynthesis of a very complex and ordered structure : the plant starch granule.
での光合成を緊密に共役させているだけでなく、アミロプラス トでの貯蔵澱粉の合成においても機能しているように思われ る。ADP-グルコースピロホスホリラーゼが澱粉生合成に必須の 律速段階であることは、遺伝学的にも分子生物学的にもかなり

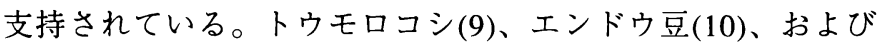
Arabidopsis(11)でこの酵素活性の減少した変異体では、それに相 当して澱粉生合成の速度と澱粉含料が減少していた。ジャガイ モにおいて、この酵素の一方のサブユニットを標的にしたアン チセンスRNAの導入により、酵素活性とそれに比例した港粉含 量の減少がみられた(12)。Arabidopsisでは完全に酵素活性と澱粉 の双方を消失した変異体が得られている(13)。同様な変異体が 単細胞緑藻であるChlamydomonas reinhardtiiでごく最近得られ た。そのうえChlamydomonasでは3-PGAによる活性化に対する 感受性の低下を示す変異体も得られている(14)。これらの変異 体は、活性化されない状態で調べると野生型と同等のレベルの 酥素活性と動力学パラメーターを示すにもかかわらず、テスト したすべての条件で港粉含量が90\%低下していた。逆に、細菌 由来の高比活性を示す变異酵素の遺伝子を導入し、高発現させ たジャガイモ塊茎では澱粉含量が30から60\%増えていた(15)。プ ラスチド型のホスホグルコムターゼが葉細胞葉緑体へのグル コース1リン酸の供給に関与していることもまたArabidopsis thaliana(16)およびNicotiana sylvestris(17)の変異体を分離するこ とで確認された。しかし、おもしろいことに徹底的に研究され ているにもかかわらず、トゥモロコシや他の港粉を蓄積する作 物ではそのような変異体が報告されたことが無い。このことは グルコース-1ーリン酸のアミロプラストへの輸送を示唆する。実 際、ヘキソース輸送(グルコース-1-リン酸およびグルコース-6リン酸の両方)の決定的な生化学的証拠は最初卜ウモロコシおよ び小麦(18)で得られ、それから他の澱粉貯蔵作物で得られた(19、 20)。このようなことから、次のように推測することは非常に魅 力的である。すなわち、光合成をしないアミロプラストにはグ ルコース-1ーリン酸を含むへキソースリン酸は大量に入ってくる が、葉においての澱粉合成はカルビン回路からグルコース-6-リ ン酸に至る炭素の流れとそれに続くプラスチドのホスホグルコ ムターゼによるグルコース1リン酸への転換に頼っているであろ うということである。ADP-グルコースの合成に必要なATPは葉 緑体での光リン酸化によって生じる。光合成をしない貯蔵組織 ではATPはトウモロコシBT1遺伝子(21)によってコードされてい るようなアデニル酸輸送体を通しておそらくアミロプラストに 入ってくるものと思われる。その他の争点、例えばトゥモロコ シにおける澱粉合成の別の経路の存在、あるいは大麦もしくは 小麦の胚乳におけるひとつの特異的なADP-グルコースピロホス ホリラーゼのアイソフォームが細胞質にあるらしいなどといっ たことがらについては未だ論争の的であるのでここでは扱わな い。別の経路であるのか伝統的な経路であるのか、いずれにし ても、プラスチド内のADP-グルコースが非常に複雑かつ規則正 しい構造、すなわち植物の澱粉粒を生合成する唯一のグルコー ス供与体であると私達は結論しょう。 


\section{The Building of Amylose}

As noted above amylose is the minor (typically 15 to $30 \%$ in weight) fraction of the starch granule. It is a moderately branched polymer (up to $1 \%$ branches) of mass ranging between 0.2 to $1.3 \mathrm{kDa}$. Amylose biosynthesis can be attributed to the major granule-bound starch synthase (GBSSI or GBSS) that accounts in most cases for over $70 \%$ in weight of the total granule associated proteins. As in the case of the other granulebound and soluble starch synthases, GBSS is an ADP glucose: 1,4- $\alpha$-D-glucosyltransferase. It thus transfers glucose from the nucleotide sugar to the non reducing end of a growing a 1,4 linked chain. In fact this is the activity originally discovered by Leloir (5). Unlike other starch synthases it is to some extent able to incorporate glucose with non physiological concentrations of UDP-glucose $(5,6)$. This property disappears upon solubilization of the enzyme from the granule $(22,23)$. The $K_{\mathrm{m}}$ of GBSS for ADP-glucose is very high when the enzyme is bound to starch. Again this $K_{\mathrm{m}}$ drops to levels comparable to the soluble starch synthases when the enzyme is released from the granules $(22,23)$. The involvement of GBSS in amylose biosynthesis was clearly demonstrated by genetic experiments. Waxy mutants of maize containing wild-type amounts of starch with no amylose have been shown to be defective for GBSS (24). The mutants either lacked the GBSS protein or harbored a modified enzyme activity. Similar mutants have been obtained in a great number of species including rice (25), barley (26), potato (27) and Chlamydomonas (28). In all these cases, the defective gene product was shown to be the GBSS protein. GBSS catalyzes a step in amylose biosynthesis which seems to be at least in some physiological conditions rate-limiting. Gene dosage experiments performed on hexaploid and triploid maize endosperms clearly showed a linear increase of the activity with the number of wild-type genes. In the same experiments an increase in amylose content correlated with the increase of the wild-type allele dose (29). This increase was not strictly proportional and peaked at two-fold while the activity increased 3 to 6 fold. Since these experiments have been carried out, a number of waxy genes and cDNAs have been cloned, allowing molecular approaches to this problem (45). Similar results were obtained with transgenic potato tubers containing antisense constructs directed against GBSS (30). In this case however, interpretation of the results are further complicated by interferences due to the possible developmental regulation of expression of both the GBSS and the antisense genes. Thus we are left with an overwhelming case for the involvement of the major granule-bound ADPglucose:1,4- $\alpha$-D-glucosyltransferase in the synthesis of the amylose fraction. In storage tissues amylose and amylopectin are synthesized asynchronously. It is known that starch from young maize kernel endosperms contain far less amylose than mature kernels. The same observation holds for rice, bar-

\section{C. アミロースの構築}

先に述べたように、アミロースは澱粉粒の少ない方の成分 (典型的には15から30重量\%)である。アミロースはわずかの分岐

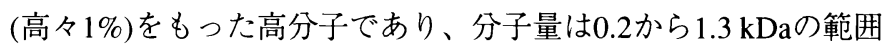
である。アミロースの生合成は、往々澱粉粒結合タンパク質の $70 \%$ 以上をも占める港粉粒結合型スターチシンターゼの主成分 (GBSSIあるいはGBSS)によって行われる。他の澱粉粒結合型お よび可溶性スターチシンターゼの場合と同様に、GBSSはADPグルコース: 1,4- $\alpha$-D-グルコシルトランスフェラーゼであり、糖 ヌクレオチド由来のグルコースを伸長しつつある 1,4 結合した糖 鎖の非還元末端に転移する。実はこの活性がLeloir(5)により最 初に発見されたものである。他のスターチシンターゼと違っ て、本酵素は生理的に意味のある濃度をこえたUDP-グルコース からは、アミロースにグルコースをある程度取り込むこともで きる(5、6)。この性質は澱粉粒から酵素を可溶化したときに消失 する(22、23)。GBSSのADP-グルコースに対する $K_{\mathrm{m}}$ 值は酵素が澱 粉に結合しているときは非常に高いが、酥素が澱粉粒から離れ ると可溶性スターチシンターゼと同等のレベルまで低下する (22、23)。GBSSがアミロースの生合成に関与していることは遺 伝学的な実験から明らかにされた。トウモロコシのWaxy変異体 は野生型と同じくらいの澱粉を含むにもかかわらずアミロース が存在しないが、これはGBSSの欠損であることが示されている (24)。これの変異体はGBSSタンパク質を欠損しているかあるい は酵素活性が修飾されているかのいずれかである。同様な変異 体がイネ(25)、大麦(26)、ジャガイモ(27)、およびChlamydomonas(28)など、多くの植物種で得られてきている。これらすべ ての場合に执いて、久損している遺伝子産物はGBSSタンパクで あることが示されている。GBSSは少なくともある生理的条件下 ではアミロースの生合成の律速段階となっていると考えられる ステップを触媒している。6倍体および3倍体のトウモロコシ胚 乳において行われた遺伝子増幅実験では、野生型遺伝子の数に 比例して活性がはっきりと増大した。同じ実験において、アミ ロース含量も野生型対立遺伝子の分量に応じて増大した(29)。 この増加は厳密には比例関係ではなく、活性の3から6倍の増加 に対して2 倍が最高であった。これらの実験が行われてから、 多くのWaxy遺伝子およびcDNAがクローン化され、この問題に ついて分子的にアプローチすることが可能になった(45)。GBSS に対してのアンチセンス組み換え遺伝子を含むトランスジェ ニック馬鈴薯塊茎を用いて同じような結果が得られている (30)。しかしながらこの場合は、GBSSおよびアンチセンス遺伝 子の発現が発達に伴って制御されるかもしれないという問題が あるため、結果の解釈がさらに複雑である。このように、澱粉 粒結合型ADP-グルコース: 1,4- $\alpha-\mathrm{D}-$ グルコシルトランスフェ ラーゼの主成分がアミロース画分の合成に関与していることに ついては圧倒的な事例が示されている。貯蔵組織においてはア ミロースとアミロペクチンの合成は同調していない。トウモロ コシの未熟な肧乳の澱粉は成熟したそれよりもはるかにアミ ロースが少ないことが知られている。同様なことが、米、大 
ley, wheat, peas and potatoes [for a review, see (30)]. In Chlamydomonas, growth arrested cells will accumulate large amounts of a polysaccharide that we are unable to distinguish from maize endosperm storage starch (32). This starch harbors normal amylose amounts (28). Chlamydomonas further mimicks higher plants by showing during storage a similar increase with age of the amylose content. However, the structure and composition of starch that was purified from growing cells came as a total surprise (33). Not only is there less polysaccharide but the granules also harbor very little or no amylose. Surprisingly, the absence of amylose correlates with a very spectacular increase in specific GBSS activity (33). This means that GBSS while being required for amylose biosynthesis is clearly not sufficient to allow synthesis of this starch fraction during growth and photosynthesis. We believe that the additional factors required might be either the absence of a particular enzyme or the presence of specific physiological conditions leading to a high supply of ADP-glucose. These two apparently very different explanations are not necessarily mutually exclusive since modification in starch synthesis and content might directly or indirectly lead to changes in enzymatic balances on the granule's surface. That the additional factor is the presence of another protein selectively needed for amylose synthesis seems unlikely. Unless the protein was needed for cell survival, this would have lead by now to the identification of a second waxy locus in the most intensively studied plant species.

Branching enzymes (1,4- $\alpha$-D-glucan: 1,4- $\alpha$-D-glucan 6- $\alpha$-D-(1,4- $\alpha$-D-glucano)-transferases) remain however good candidates for proteins acting negatively on amylose biosynthesis. The evidence supporting this stems from genetic interaction studies performed in maize. It is known that, in corn, the waxy mutations are epistatic over all other defects in starch biosynthesis [(34), for review see (30)]. This means that inbred lines carrying a homozygous $w x$ defect will never contain amylose. The only exception to this rule are the double mutants homozygous for both $w x$ and $a e$ (the $A E$ locus is the branching enzyme II (BEII) structural gene). In these double mutants the amylopectin becomes less branched while the dispersed glucans adopt a bimodal or even in some cases trimodal size distribution upon gel filtration $(35,36)$. The molecular weight of the smaller and minor peak is that of amylose while that of the second is intermediate between amylose and normal amylopectin [a situation reminiscent of type II amylopectin (see below)]. The excluded fraction contains the atypical moderately branched amylopectin. It is not clear from the published data that the structure of the small size material is significantly different from that of the loosely branched amylopectin. In any case this material does not comply either to the definition of amylose (because of higher branching) nor to that amylopectin (because both of small size and lower branching). Thus in the absence of GBSS activity and provided BEII is absent, the re-
麦、小麦、エンドウ豆、およびジャガイモで観察されている[総 説としては(30)]。Chlamydomonasにおいては、増殖を抑制され た細胞はトゥモロコシ胚乳の貯蔵港粉と区別できない多量の多 糖類を蓄積する(32)。この澱粉は通常のアミロース量を示した (28)。Chlamydomonasは(増殖を抑制した状態で)貯蔵しておく と、時間とともにアミロース含量の増加がみられるという点で さらに高等植物に似ている。しかしながら、增殖中の細胞から 精製した澱粉の構造と構成は全く驚くべきものであった(33)。 多糖の量が少ないだけでなく、この澱粉粒にはほとんどあるい は全くアミロースが存在しなかったのである。驚いたことに、 アミロースの欠如は特定のGBSSの活性の劇的な増加と相関して いた(33)。このことはGBSSがアミロースの生合成に必要ではあ るものの、増殖と光合成の過程においてこの澱粉区分を合成す るのには、それだけでは不十分であることを明らかにしてい る。私達はこの必要とされる追加的要因として、特定の酔素の 欠如あるいはADP-グルコースの供給を高める特定の生理的条件 の存在があると考えている。これら2つの事柄は一見したところ 大きく違った説明にみえるが、かならずしも相反しない。なぜ ならば、澱粉合成㧍よび澱粉含量の変化は直接的あるいは間接 的に澱粉粒表面での酵素バランスの变化の原因となるかもしれ ないからである。アミロース合成に選択的に必要なもうひとつ のタンパク質の存在という追加要因の可能性は低い。もしそう したタンパク質が存在し、かつそれが細胞の生存に必須でない ならば、この最も精力的に研究されている植物種における2番目 のwaxy 遺伝子座の発見につながっていたはずである。

一方、ブランチング酵素(1,4- $\alpha$-D-グルカン: $1,4-\alpha-\mathrm{D}-$ グル カン 6- $\alpha$-D-(1,4- $\alpha$-D-グルカノ)-トランスフェラーゼ)はアミ ロース生合成に負に作用するタンパク質の候補と考えることが できる。これを遺伝子の相互関係から裏付ける証拠がトウモロ コシにおいて得られている。トウモロコシにおいてはwaxy変異 は澱粉生合成に扔けるどの欠損に対しても遺伝的に上位に位置 している[(34)、総説としては(30)]。このことはwx欠損をもつホ モ接合体型の近交系はアミロースを決して含まないことを意味 する。この唯一の例外は $w x$ 㧍よび $a \mathrm{e}(A E$ 遺伝子座はブランチン グ酵素II(BEII)の構造遺伝子である)の両方のホモ接合変異株で ある。この二重変異株においてはアミロペクチンの枝分れが少 なくなる一方、グルカン画分を溶媒に分散してゲルろ過すると

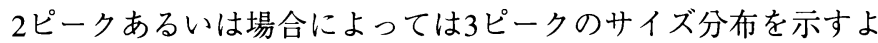
うになる $(35 、 36)$ 。低分子量側で、量的にも少ないピークの分子 量はアミロースに対応し、2番目のものの分子量はアミロースと 通常のアミロペクチンの中間に位置する[タイプIIアミロペクチ ン(以下参照)を思い出させる]。また、排除限界に溶出される画 分は、通常のものと異なった、分岐度の低いアミロペクチンで ある。公表されたデータからでは、低分子量側の物質の構造が この分岐の少ないアミロペクチンと有意に異なるかどうか明ら かではない。いずれにしても、この物質はアミロースの定義か らも(なぜならば高度に分岐している)アミロペクチンの定義から も(なぜならば分子サイズも小さく、分岐度も低い)はずれる。こ のように、GBSS活性を欠き、またBEIIが無い場合には、残った 
maining soluble starch synthases are able to synthesize fractions of intermediate structure between amylose and amylopectin. This suggests that the soluble starch synthases have the biochemical potential to synthesize linear glucans but that they are overpowered in vivo by the branching enzymes. During storage it is evident that GBSS is not overpowered by the branching enzymes. However this situation is likely to be changed in growing or photosynthesizing cells and could lead to synthesis of amylopectin by GBSS (see below). In fact, clear-cut direct evidence for the involvement of GBSS in the building of amylopectin has been obtained from growing Chlamydomonas cells (33).

An alternative simple explanation for the lack of amylose synthesis in specific physiological conditions resides in the high $K_{\mathrm{m}}$ of the bound enzyme for ADP-glucose $(22,23)$. We can hypothesize two populations of GBSS. The first would be located at the very surface of the granule and would have access to all the soluble enzymes necessary to obtain amylopectin. The second would be less accessible and involved in amylose biosynthesis because of its physical isolation from the other enzymes. It is the latter which which would be responsible for the high $K_{\mathrm{m}}$ of the granule-bound activity. When in presence of high amounts of ADP-glucose (as in storage) amylose synthesis would thus occur through GBSS on the granules while in low nucleotide sugar supply this activity would be unable to do so. Thus as noted above the supply of ADP-glucose will control starch composition. That this is indeed the case is suggested by our recent observation that mutants impaired either in ADPglucose pyrophosphorylase or phosphoglucomutase display structural phenocopies of the starch extracted from growing cells. Such mutants with reduced amounts of starch and ADPglucose have no traces of amylose.

\section{The Building of Amylopectin}

Amylopectin synthesis is likely to be more complicated than both amylose and glycogen synthesis. Fig. 1 shows that the branched clusters of amylopectin are composed of amorphous and cristalline lamellae. It has been shown that the sum of both lamellae in a single cluster amounts precisely to $9 \mathrm{~nm}$ in all plant species examined (4). The clusters alternate in a highly regular fashion with amorphous regions of the molecule. The amorphous lamellae inside the clusters contain a very high density of closely spaced branches $(1,2)$. The close spacing of the branches is responsible for maintaining the chains in parallel position facilitating the formation of the glucan double helices. We have known for years that the enzymes necessary for the synthesis of the $\alpha 1,4$ (starch synthases) and the $\alpha 1,6$ linkages are present in plants [for reviews, see (37-39)]. In maize 2 distinct branching enzymes (BEI and BEII) and 2 soluble starch synthases (SSSI and SSSII) have been identified $(40,41)$, purified and intensively studied. All these enzymes are the prod-
可溶性スターチシンターゼはアミロースとアミロペクチンの中 間のようなものを合成する。このことは可溶性スターチシン ターゼは直鎖のグルカンを合成する生化学的能力をもつが、生 体内ではブランチング酵素がより高い活性をもっている(従って その影響が強く出る)ことを示唆している。貯蔵中ではブランチ ング酵素がGBSS活性を上回ることがないのは明らかである。し かしながら、増殖過程あるいは光合成中の細胞においては状況 はおそらく異なっており、GBSSによるアミロペクチンの合成が 起こり得る(以下参照)。事実、GBSSがアミロペクチンの構築に 関与している明瞭な証拠が増殖中のChlamydomonas細胞から得 られている(33)。

特定の生理的条件でアミロースが合成されないことに関す る別の簡単な説明は、粒結合型の酵素がADP-グルコースに対し て高い $K_{\mathrm{m}}$ 值を示すということの中に見いだすことができる(22、 23)。我々はGBSSには2つのタイプがあるという仮説を考えるこ とができる。ひとつは澱粉粒のごく表面に存在し、アミロペク チンを合成するのに必要なすべての可溶性酵素と接近すること ができるであろう。もうひとつは、そのような酵素が接近しに くく、他の酵素から物理的に隔離されることでアミロースの生 合成に関与しているのであろう。澱粉粒結合型活性の高い $K_{\mathrm{m}}$ 值 は後者のせいであろう。このような仕組みにより、ADP-グル コースが大量に存在するとき(貯蔵時のように)には、澱粉粒の GBSSによってアミロース合成が起こるが、糖ヌクレオチドの供 給が少ないときにはこの反応は進まないのであろう。このよう にして先に述べたようにADP-グルコースの供給が澱粉の組成を 制御する。最近、私達はADP-グルコースピロホスホリラーゼあ るいはホスホグルコムターゼのどちらかを損なった变異体から 得られた澱粉が、増殖過程の細胞から抽出した澱粉と同様の構 造を示すことを観察しているが、これがまさに上に述べたよう な事情を示唆するものと考えられる。そのような变異体では澱 粉やADP-グルコースの量も低下しているし、アミロースも全く 無い。

\section{D. アミロペクチンの構築}

アミロペクチンの合成はアミロースおよびグリコーゲンの 合成よりもさらに複雑であると思われる。図1はアミロペクチン の枝分れした房が無定形および結晶性の薄層から構成されてい ることを示している。単一の房における両薄相の合計は調べら れたすべての植物で正確に $9 \mathrm{~nm} に$ 達することが示されている (4)。これらの房はその分子の無定形の領域と非常に規則正しく 交互になっている。房のなかの無定形の薄層は非常に高密度で 間隔の近い枝分れを含んでいる $(1 、 2)$ 。間隔の近い枝分れは鎖を 平行の位置に維持し、グルカンの二重らせんを形成するのに役 立っている。私達は以前から $\alpha 1,4$ (スターチシンターゼ)および $\alpha 1,6$ 結合の合成に必要な酵素が植物に存在することを知ってい る[総説としては(37-39)]。トゥモロコシにおいては2つのブラン チング酵素(BEIおよびBEII)と2つの可溶性スターチシンターゼ (SSSIおよびSSSII)が同定されていて $(40 、 41) 、$ 精製され集中的に 研究されてきた。これらすべての酵素は別々の遺伝子産物であ 
ucts of distinct genes and differ by their substrate specificities or the structures they generate. Understanding their in vivo function however is further complicated by the recent observation that maize BEI and (or) BEII expressed in a E. coli branching enzyme deficient mutant generate a quite different structure from that observed in vitro (42). Recent reviews (37-39) have well covered the biochemical properties of these branching and elongation enzymes, we will thus focuss our attention on the genetic evidence supporting their proposed functions. Suffice it to say here that SSSI and SSSII display similar affinities for ADP-glucose but differ by their primer specificities and their reaction to high concentrations of citrate. Of particular importance is the observation that SSSI has a marked preference for glycogen while SSSII elongates amylopectin more efficiently. From this observation it was proposed that SSSI would favor the short exterior chains (A chains) while SSSII might prefer the longer B chains (39). Maize BEI and BEII also differ by their substrate preference and the type of branches they produce $(43,44)$. BEI is particularly efficient for branching of amylose and branched amylopectin at $5 \%$ of the amylose branching rate. BEII branched amylopectin at twice the rate it branched amylose and 6 fold faster than BEI. Moreover the chain sizes transfered by BEI were greater than those transfered by BEII. All plant systems to date seem to contain SSSI and SSSII-like activities. This might not be the case for the two branching enzymes which have both been shown to be present in cereal endosperms and pea embryos. The existence of BEII in potato tubers however is presently controversial.

From a genetic point of view, maize has been the most intensively studied plant system. Five loci have been described that interfere with the building of the granule's architecture (others such as $S h 1, S h 2, B t 1, B t 2$ interfere with the supply of ADP-glucose). These are $W x$ (waxy), $A e$ (amylose extender), $D u$ (dull), Sul (sugary) and Su2. Wx is the GBSS structural gene (45) and has been shown to be necessary for amylose biosynthesis (see above). Ae is the maize equivalent of the pea $R$ locus originally defined by Gregor Mendel (46). Both loci ( $R$ and $A e$ ) have now been shown to encode type II branching enzymes $(46,47)$. $D u$ has been shown to be defective for both one particular isoform of BEII (BEIIa) and SSSII $(48,49)$. sul mutants have been shown to lack a specific debranching enzyme (61). No defective function was reported for su2 mutants. $a e$ and $r$ mutants display very similar phenotypes. They both have a modest decrease in starch amounts and a drastic increase in amylose content. Moreover they accumulate both novel low and intermediate molecular weight fractions known as intermediate materials (50). The residual amylopectin is considerably modified with a decrease in branching and an increase in the number of long chains. The mutants from peas and maize exhibit a B X-ray diffraction pattern while the wild-type and all other mutant starches (including in the presence of $s u 2$ or $d u$ )
り、基質特異性あるいはそれらが作り出す構造も異なってい る。しかしながらこれらの生体内での機能を理解することは もっと複雑であることが、大腸菌のブランチング酵素の欠損株 においてトウモロコシBEIおよび(または)BEIIを発現させた時 に、試験管内での実験で観察された構造と大幅に異なった構造 が作り出されるという最近の研究からも示される(42)。最近の 総説(37-39)はこれらのブランチング酵素および伸長酵素の生 化学的性質についてよく書かれているので、私達はこれらの酵 素の機能に関する仮説を支持する遺伝学的証拠に焦点をあてる ことにしょう。ここではSSSIおよびSSSIIがADP-グルコースに 対して同様の親和性をしめすが、プライマーの特異性とクエン 酸高濃度下での反応が異なっていることについて述べておけば 十分である。特に重要なことはSSSIがきわだってグリコーゲン を好むのに、SSSIIはアミロペクチンをより効率的に伸長させる という知見である。この結果からSSSIは短い外部の鎖(A鎖)を好 み、SSSIIは長いB鎖を好むであろうという提案がなされた (39)。トウモロコシBEIおよびBEIIもまた基質の好みや作り出す 枝分れのタイプが異なっている(43、44)。BEIは特にアミロース の枝付けを効率良く行い、アミロペクチンではアミロースの $5 \%$ の速度である。BEIIはアミロペクチンをアミロースの2倍の速度 で枝付けし、それはBEIよりも6倍も速い。そのうえBEIで転移 される鎖の長さはBEIIによるそれよりも大きい。現在までに報 告されているすべての植物でSSSIおよびSSSIIに似た活性が含ま れている。穀物の胚乳およびエンドウ豆の胚で存在が示されて いる二つのブランチング酵素はこの事例にあてはまらないかも しれない。ジャガイモ塊茎のBEIIの存在は今のところ論争の余 地がある。

遺伝学的な見地から言えば、トウモロコシは最も徹底的に 研究された植物系である。5つの遺伝子座が澱粉粒の構造の構築 にかかわるといわれている(他の座Shl、Sh2、Btl、およびBt2な どはADP-グルコースの供給に関わっている)。これら5つは、 $W x$ (waxy)、Ae(amylose extender)、Du(dull)、Sul(sugary)、および Su2である。WxはGBSSの構造遺伝子であり(45)、アミロースの 生合成に必要であることが示されている(上述)。Aeはエンドウ 豆のR遺伝子座に相当し、Gregor Mendelにより初めて定義され

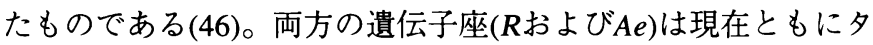
イプIIのブランチング酵素をコードしていることが示されている (46、47)。DuはBEII(BEIIa)およびSSSIIの両方においてひとつの 特別なアイソフォームが欠損していることが示されている(48、 49)。sul変異株は特定の枝切り酵素が欠損していることが示さ れている(61)。Su2変異株については機能の欠損は報告されてい ない。aeおよび $r$ 変異株は非常に似た表現型を示す。それら両 方は若干の澱粉含量の減少と劇的なアミロース含量の増加がみ られる。そのうえ、それらは中間物質として知られる独特の低 あるいは中程度の分子量の区分を蓄積する(50)。残りのアミロ ペクチンは構造がかなり変化しており、枝分れが少なく長い鎖 の数が多くなっている。エンドウ豆およびトウモロコシの変異 株はBタイプのX線回折パターンをとるが、野生型あるいはすべ ての他の变異株(su2あるいは $d u$ 变異の存在下を含む)の澱粉は標 
still display the classical cereal A type (31). It is striking to note that if the absence of BEII in potato tubers was to be confirmed, it would correlate with the specific B type of X-Ray diffraction pattern displayed by potato tuber amylopectin. In yeast, we have proven that a knock-out of glycogen branching enzyme leads to a considerable decrease in glycogen synthesis (52). This is clearly not the case for BEII. We believe that the phenotypes of the BEII mutants point to a downstream function for this enzyme in the starch biosynthetic pathway. Indeed, the BEII defective mutants still have $9 \mathrm{~nm}$ amylopectin clusters with reduced amorphous lamellae and increased crystalline lamellae yielding B type diffraction patterns. A selective downstream action of BEII on the amylopectin cluster architecture correlates with what we now know about its in vitro preference for amylopectin and its ability to transfer short chains. Yet, even if in vivo BEII functions predominantly as a downstream enzyme, one cannot exclude that it could partly substitute for a BEI deficiency. This objection seems all the more valid if one considers that branching enzyme activities are in vast physiological excess. The problem of partial functional redundance complicates considerably all studies dealing with starch biosynthesis and will also be encountered with the starch synthases. No mutants to date have been reported to be defective for BEI. Both $d u$ and $s u 2$ carrying mutants are characterized by a relative enrichment in amylose content and a decrease in the number of intermediate size chains in amylopectin (53, 54). In combination with $w x$ they only accumulate amylopectin. However this polysaccharide was reported in both cases to harbor more short (A and B1 chains) chains than waxy amylopectin (55). In Chlamydomonas similar mutants defining also 2 distinct loci (STA3 and STA4) have been described $(56,33)$. One of these has an established enzymological defect. sta-3 carrying mutants lack all SSSII activities and display a dramatic decrease in the number of amylopectin chains whose length ranges between 8 to 40 glucose residues (56). The mutants have a 50 to $70 \%$ decrease in starch content. In the presence of an additional disruption in the GBSS structural gene the starch level falls beneath $5 \%$ of wild-type levels which cannot be accounted by the sole disappearance of amylose (57). Moreover double mutants carrying a sta 3 mutation and progressively more severe sta 2 point mutations display a decrease in the number of amylopectin long chains (57). The severity of this decrease comes as simple function of the residual mutant GBSS activity. These facts strongly suggest that GBSS is not only an amylose biosynthetic enzyme but is also an important enzyme for the building of the long B chains of amylopectin (B3, B4, B5 chains) (57). This conclusion is also supported by a recent report establishing that the cristalline lamellae of the amylopectin cluster is significantly shorter in waxy amylopectin (58). This can indeed be easily explained if one assumes that GBSS participates in cluster biosynthesis. All mutants defective for
準的な款物のA夕イプを示す(31)。ジャガイモ塊茎においてBEII の欠損が確認されれば、ジャガイモ塊茎のアミロペクチンが特 異なB夕イプのX-線回折パターンを示すことと関連させること ができるが、これはおおいに注目される点である。酵母におい ては、グリコーゲンブランチング酵素をこわすとグリコーゲン 合成がかなり低下する(52)。これは明らかにBEIIの場合と異 なっている。私達はBEII变異株の表現型は澱粉の生合成経路の 下流に位置する機能にあてはまると信じている。実際、BEII欠 損変異株でも、無定形の薄層が減少し結晶性の薄層が増加した 9nmのアミロペクチンの房をもち、B夕イプの回折パターンを示 す。アミロペクチンの房を構築する場合の下流の反応における BEIIの選択的役割は、試験管内実験で得られた、BEIIがアミロ ペクチンを好み、かつ短い鎖を転移する能力をもつことに関連 づけられる。生体内でのBEIIの機能が主に下流の酵素であると してもなお、それがBEIの欠損を部分的に補填する可能性を除外 することはできない。このことは、ブランチング酵素の活性が 生理的に大過剩であることを考えた場合、より根拠のあること であると思われる。部分的な機能の重複という問題は澱粉生合 成を扱う研究すべてをかなり複雑にしているし、スターチシン ターゼでも同様なことに出くわす。今までのところ、BEIの欠損 した変異株は報告されていない。duおよびsu2変異の両方をもつ 株はアミロース含量が比較的多く、アミロペクチンの中間的な サイズの鎖の数が減少している(53、54)。これにwx変異が加わる とアミロペクチンだけが蓄積する。しかしながら、この両方の 事例においてこれらの多糖類はwaxyアミロペクチンよりも短い 鎖(AおよびB1鎖)をもっている(55)。Chlamidomonasにおいても やはり2つの明確に区別される遺伝子座(STA3およびSTA4)に対応 した類似の変異体が報告されている(56、33)。これらのうちひと つは酵素の欠損が確認されている。 sta-3変異をもつ变異株では すべてのSSSII活性が欠損して扔り、アミロペクチンの鎖の長さ も劇的に減少し、8から40グルコース残基である(56)。この变異 体では澱粉含量が50から70\%減少している。GBSSの構造遺伝子 の破壊がこれに加わると、澱粉のレベルは野生型の5\%以下に減 少し、これはアミロースだけが消失したことでは説明がつかな い(57)。さらに、sta3変異とよりきびしい変異のsta2の点変異の 二重変異をもつ株ではアミロペクチンの長い鎖の数が減少して いる(57)。この減少の程度は残存する变異GBSSの活性によって 左右される。これらの事実から、GBSSはアミロースの生合成酵 素であるばかりでなく、アミロペクチンの長いB鎖(B3、B4、お よびB5鎖)を構築するのに重要であることが強く示唆される (57)。この結論はアミロペクチンの房の結晶性薄層がwaxyアミ ロペクチンでははっきりと短くなっていることを明らかにした 最近の報告(58)によっても支持される。このことはGBSSが房の 生合成に関与していると考えれば害に簡単に説明できる。SSSII を欠損しているすべての变異株では非常に選択的にアミロペク 
SSSII have a very selective increase in the small glucans of amylopectin with a typical maximum in the number of chains with $6 \mathrm{Glc}$ residues. Interestingly this distribution was also reported for that of the glycogen produced in E.coli in the presence of the maize branching enzymes (42). In Chlamydomonas, mutants defective for both GBSS and SSSII synthesize minute amounts of granular material whose branching is intermediate between glycogen and amylopectin (57). The presence of abundant small glucans in this material argues in favor of the role proposed for SSSI in the building of the A and small B chains. It is worth noting that the maize $d u$ carrying mutants behave much like the Chlamydomonas SSSII defective strains. SSSII was reported to be defective in $d u$ carrying mutants (48, 49). However, since BEIIa was also lacking a regulatory function was proposed for that locus. In Chlamydomonas a second locus (STA4) was identified that led to similar defects that were exclusively witnessed during storage (33). However the small glucans of the sta 4 mutants displayed a distinct highly specific size distribution. No enzymological defects were scored neither in Chlamydomonas sta 4 nor in maize su 2 carrying mutants. The failure to find these defects suggest that in addition to the well characterized elongation and branching enzymes other functions might be required to build mature amylopectin clusters. Another example of this stems from the biochemical investigations performed with the maize sul mutants. Homozygous sul mutants have a significant reduction $(50 \%)$ in starch content that correlates with the appearance of phytoglycogen (59). This fraction defines a water soluble polysaccharide with a degree of branching and other physico-chemical properties analogous to those displayed by standard glycogen. The finding of phytoglycogen in sweet corn led Erlander back in 1958 (60) to propose that glycogen was a precursor of normal starch synthesis. Partial debranching of phytoglycogen would lead to the synthesis of amylopectin while complete debranching would yield amylose. Erlander's proposal led many investigators to purify debranching enzymes from wild-type and sweet corn. While the results obtained by different laboratories lead to divergent interpretations, a convincing report has been made concerning a selective decrease in debranching activity in the mutants (61). Pan and Nelson despite this finding have argued that debranching and branching activities are balanced in the maize endosperm in a way that yields the observed A to B chain ratios in amylopectin (61). In that sense phytoglycogen would not be a natural precursor for starch biosynthesis. While we are still very far from understanding the biochemical defects in sweet corn and their phenotypic consequences we would like to propose here that glucan trimming is required to build both amylopectin and amylose. The concept of glucan trimming although presently entirely speculative is especially attractive because it would explain how the close spacing of branches of the amylopectin cluster amorphous lamella could be generated
チンの短いグルカン鎖が増加しており、典型的には6つのグル コース残基からなる鎖がもっとも多くなっている。おもしろい ことに、この分布はトウモロコシ由来ブランチング酵素を発現 させた大腸菌が生産するグリコーゲンでも報告されている (42)。Chlamidomonasにおいては、GBSSおよびSSSIIの両方を欠 損した変異株は微量の顆粒物質を合成し、その分岐度はグリ コーゲンとアミロペクチンの中間であった(57)。この物質のな かに短いグルカン鎖が豊富に存在することはSSSIがA鎖と短いB 鎖を形成するという提案を支持する。トウモロコシのdu変異株 がChlamidomonasのSSSII欠損株とよく似ているということは注 目に值する。SSSIIは $d u$ 変異をもつ変異株では欠損していること が報告されている(48、49)。しかしながら、BEIIaもまた制御機 能がないことがこの遺伝子座に関して提案されている。 Chlamidomonasにおいては、貯蔵時にのみ目撃される類似の欠 損を引き起こすものとして2番目の遺伝子座(STA4)が同定されて いる(33)。しかし、sta4変異株の短いグルカン鎖は非常に特異的 な分子量分布を示す。Chlamidomonasのsta4あるいはトウモロコ シのsu2の変異株では酵素的な欠損は見い出されなかった。こう した欠損が見つからなかったことは、よく研究された伸長酵素 と枝付け酵素に加えて、さらに他の機能が成熟したアミロペク チンの房を形成するのには必要なことを示唆している。生化学 的研究から得られるもうひとつの重要な例はトウモロコシsul変 異株を用いて示された。ホモ接合型のsul变異株では澱粉含量が

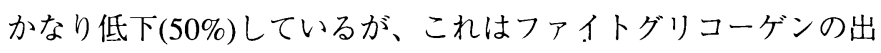
現と関連している(59)。この区分(ファイトグリコーゲン)は分岐 の度合いや物理化学的性質が通常のグリコーゲンに似た水溶性 多糖として定義される。Erlander(60)によりスイートコーンから ファイトグリコーゲンが発見されたのは1958年であり、彼はグ リコーゲンは正常な澱粉の合成の前駆体であると提案した。 ファイトグリコーゲンを部分的に枝切りするとアミロペクチン の合成となり、完全に行うとアミロースが得られるであろうと いうものである。Erlanderのこの提案をもとに、多くの研究者が 野生型およびスイートコーンから枝切り酵素を精製した。それ ぞれの研究室で得られた結果により、色々な解釈がされたが、 この変異株において枝切り酵素が選択的に減少していることを 示した説得力のある報告がなされた(61)。PanおよびNelson(61) はこの発見にもかかわらず、トウモロコシ胚乳では枝切りと枝 付け活性がある意味で釣り合いを取ってアミロペクチンのA鎖 とB鎖を観察されるような割合にしているのだと主張した。その 意味ではファイトグリコーゲンは澱粉生合成の自然な前駆体で はないだろう。私達はスイートコーンにおける生化学的欠陥と その表現型への影響を理解するには未だ程遠いが、ここではア ミロースやアミロペクチンの構築にはグルカンのトリミングが 必要であると提案したい。グルカンのトリミングという概念は 現在のところ完全に推定の域を出ないが、これがアミロペクチ ンの房の無定形薄層部分における非常に密集した分岐構造をど 
by the branching enzymes. One can assume that phytoglycogen is generated in plants by BEI and BEII which are in vast excess just as glycogen is synthesized in vivo by the expression of the same enzymes in E. coli (42). As was documented in E.coli very closely spaced branches are likely to be produced among moderately and loosely spaced branches. A selective debranching enzyme would then be responsible for clipping off those moderately or loosely spaced branches leaving the mature future amorphous lamella of the amylopectin cluster to be elongated by the starch synthases without further branching. The close spacing of the branches will favor formation of parallel double helices which will achieve a particularly dense packing of glucose in the structure. This dense packing seems indeed to have been the natural selection drive behind the appearance of starch in plants.

\section{E. Perspectives}

Although in theory starch could be synthesized by the sole combination of elongation and branching enzymes, we believe that additional enzyme activities are required to tailor the highly ordered dense glucan packing observed in the amylopectin clusters. Splicing and trimming of glucans are in this respect especially attractive mechanisms. If these were to be confirmed by cloning of the maize sul locus and identification of debranching enzyme as its gene product, many questions would still remain unanswered. In particular what specifies the $9 \mathrm{~nm}$ cluster size, what prevents amylose from becoming branched, is amylopectin synthesis a prerequisite to amylose biosynthesis, what is the priming mechanism ? We believe that the random selection of new mutants and the complete characterization of preexisting ones (such as those carrying $s u 1, s u 2$ and $d u$ in maize) is the best way to probe the unknown. With the exception of genes known by virtue of their gene products, most are defined by mutations that confer particular phenotypes and the initial characterization of phenotype is frequently the way in which new biological phenomena are discovered (62).
のようにしてブランチング酵素が作り出せるのかを良く説明で きる点で特に魅力的である。大腸菌でBEIおよびBEIIを発現させ てグリコーゲンを生成させたように(42)、植物でも大過剩に存 在するこれらの酵素がファイトグリコーゲンを生成していると 仮定することが可能である。大腸菌でも証明されたように、非 常に近接した枝は中間的およびばらばらに間隔のあいた枝のな かに作られるらしい。そして選択的に働く枝切り酵素がそれら の中間的あるいはばらばらに間隔のあいた枝を刈っていき、将 来アミロペクチンの房の無定形薄層となる部分を残し、この部 分がそれ以上の枝分かれをすることなくスターチシンターゼに より伸長されると考えられる。接近した枝は平行の二重らせん を形成するのに都合がよく、構造中にグルコースを特に密に詰 め込むのに役立っている。この(グルコースの)密な詰め込みこそ が植物の澱粉の出現の背景にある自然の選択であるようにみえる。

\section{E. 展 望}

理論的には澱粉は伸張と枝付け酵素の組み合わせのみによ り合成され得るが、私達は、アミロペクチンの房のなかに見ら れるこの高度に秩序だって密に詰め込まれたグルカン鎖を仕立 て上げるには、別の追加の酵素活性が必要であると信じてい る。グルカン鎖の組み継ぎやトリミングはこの見地から特に魅 力的な機構である。こうしたことが、トウモロコシのsul遺伝子 座のクローニングおよびその遺伝子産物の枝切り酵素の同定に よって確認されても、多くの疑問が答えられないまま残るであ ろう。特に、房の大きさを $9 \mathrm{~nm} に$ 特定するのは何か、アミロー スに枝をつけるのを妨げているのは何か、アミロペクチンの合 成はアミロース生合成の先行条件か、合成開始の機構はなにか (などの問題が残っている)。新しい変異株の無作為選択と既に存 在している変異株(例えばトウモロコシのsul、su2、および $d u$ 変 異)の特性を十二分に解析することが、これら未知の疑問を解明 する最も良い方法であると私達は考えている。遺伝子産物の側 から明らかにされた遺伝子を例外として、ほとんどの遺伝子は 特定の表現型を与える変異により定義され、こうした表現型の 特性解析が新しい生物学的現象の発見の端緒となるのである (62)。

$$
\begin{aligned}
& \text { ミシガン州立大学・生化学部門 } \\
& \text { 栗木 隆訳 }
\end{aligned}
$$

\section{References}

1. Hizukuri, S. (1986)Carbohydr. Res. 147, 342-347

2. Robin, J.P., Mercier, C., Charbonnière, R., and Guilbot, A. (1974) Cereal Chem. 51, 389-406

3. Manners, D.J. (1989) Carbohydr.Polymers 11, 87-112

4. Jenkins, P.J., Cameron, R. E., and Donald, A. M. (1993) Starch/Stärke, 45, 417-420

5. Leloir, L.F, Rongine De Fekete, M.A., and Cardini, C.E. (1961) J.Biol.Chem. 236, 636-641

6. Recondo, E., and Leloir, L. (1961) Biochem. Biophys. Res. Commun. 6, 85-88

7. Copeland, L., and Preiss, J. (1981) Plant Physiol. 68, 996-1001

8. Preiss, J. (1993) Denpun Kagaku 40, 117-131

9. Tsai, C.Y., and Nelson, O.E. (1966) Science 151: 341-343

10. Smith, A.M., Bettey, M., and Bedford, I.D. (1989) Plant Physiol. 89, 1279-1284

11. Lin, T.P., Caspar, T., Somerville, C., and Preiss, J. (1988) Plant Physiol. 88, 1175-1181 
12. Müller-Röber, B.T., Sonnewald, U., and Willmitzer, L. (1992) EMBO J. 11, 1229-1238

13. Lin, T.P., Caspar, T., Somerville, C., and Preiss, J. (1988) Plant Physiol. 86, 1131-1135

14. Ball, S., Marianne, T., Dirick, L. Fresnoy, M., Delrue, B., and Decq, A. (1991) Planta 185, 17-26

15. Stark, D.M., Timmerman, K.P., Barry, G.F., Preiss, J., and Kishore, G.M. (1992) Science 258, 287-292

16. Caspar, T., Huber, S.C., and Somerville, C. (1985) Plant. Physiol. 79, 11-17

17. Hanson, K.R., and McHale N.A. (1988) Plant Physiol. 88, 838-844

18. Keeling, P.L., Wood, J.R., Tyson, R.H., and Bridges, I. G. (1988) Plant Physiol. 87, 311-319

19. Heldt, H.W., Flugee, U-I., and Borchert, S. (1991) Plant Physiol. 95, 341-343

20. Hill, L.M., and Smith, A.M. (1991) Planta 185, 91-96

21. Sullivan, T.D., Sterlow, L.I., Illingworth, C.A., Phillips, R.L. and Nelson, O.E. (1991) Plant Cell 3, 1337-1348

22. Macdonald, F.D., and Preiss, J. (1983) Plant Physiol. 73, 175-178

23. Macdonald, F.D., and Preiss, J. (1985) Plant Physiol. 78, 849-852

24. Nelson, O.E., and Rines, H.W. (1962) Biochem. Biophys. Res. Commun. 9, 297-300

25. Murata, T., Sugiyama, T., and Akazawa, T. (1965) Biochem. Biophys. Res. Commun. 18, 371-376

26. Eriksson, G. (1969) Hereditas 63, 180-204

27. Hovenkamp-Hermelink, J.H.M., Jacobsen, E., Ponstein, A.S., Visser, R.G.F., Vos-Scheperkeuter, G.H., Bijmolt, E. W., de Vries, J. N., Witholt, B., and Feenstra, W.J. (1987) Theor. Appl. Genet. 75, 217-221

28. Delrue, B., Fontaine, T., Routier, F., Decq, A., Wieruszeski, J.M., Van Den Koornhuyse,N., Maddelein, M.L., Fournet, B., and Ball, S.G. (1992) J.Bacteriol. 174, 3612-3620

29. Tsai, C-Y. (1974) Biochem. Genet. 11, 83-96

30. Kuipers, A.G.J., Jacobsen, E., and Visser, R.G.F. (1994) Plant Cell 6, 43-52

31. Shannon, J.C., and Garwood, D.L. (1984) in Starch: Chemistry and Technology, 2nd ed. (Whistler, R. L., Bemiller, J. N., and Paschall, E. F., eds.) pp.25-86, Academic Press, Orlando

32. Ball, S.G., Dirick, L., Decq, A. Martiat, J.C., and Matagne R.F. (1990) Plant Sci. 66, 1-9.

33. Libessart, N., Maddelein, M-L, Van Den Koornhuyse, N., Decq, A., Delrue, B., Mouille,G., D'Hulst,C., and Ball, S.G. (1995) Plant Cell, in press

34. Creech R.G. (1965) Genetics 52, 1175-1186

35. Yeh, J.Y., Garwood, D.L., and Shannon, J.C. (1981) Starch/Stärke 33, 222-230

36. Boyer, C.D., and Liu, K-C. (1985) Starch/Stärke 37, 73-79

37. Preiss, J., and Levi, C. (1976) in The Biochemistry of Plants. A Comprehensive Treatise, vol. 3 (Stump, E.P.K., and Conn, E.E., eds.) pp. 371-423, Academic Press, San Diego

38. Preiss, J. (1991) in Oxford Surveys of Plant Molecular and Cell Biology, vol 7 (Miflin, B.J., ed.) pp. 59-114, Oxford Univ. Press, Oxford

39. Preiss, J., and Sivak, M.N. (1996) in Photoassimilate Distribution in Plants and Crops: Source-sink Relationships (Zamski, E., and Schaffer, A. A., eds.) Marcel Dekker Inc., New York, in press

40. Boyer, C.D., and Preiss, J. (1978) Carbohydr.Res. 61, 321-334

41. Ozbun, J.L., Hawker, J.S., and Preiss, J. (1971) Plant Physiol. 48, 765-769

42. Guan, H.P., Kuriki, T., Sivak M., and Preiss, J. (1995) Proc. Natl. Acad. Sci USA, 92, 964-967

43. Takeda, Y., Guan, H.P., and Preiss, J. (1993) Carbohydr. Res. 240, 253-263

44. Guan, H.P. and Preiss, J. (1993) Plant Physiol. 102, 1269-1273

45. Shure, M., Wessler, S., and Federoff, N. (1983) Cell 35, 225-233

46. Bhattacharyya, M.K., Smith, A.M., Noel Ellis, T.H., Hedley, C., and Martin, C. (1990) Cell 60, 115-122

47. Stinard, P.S., Robertson, D.S., and Schnable, P.S. (1993) Plant Cell 5, 1555-1566

48. Preiss, J., and Boyer, C.D. (1980) in Mechanisms of Saccharide Polymerization and Depolymerisation (Marshall, J.J., ed.) pp. 161-174, Academic Press, New York

49. Boyer, C.D., and Preiss, J. (1981) Plant Physiol. 67, 1141-1145

50. Colonna, P., and Mercier, C. (1984) Carbohydr. Res. 126, 233-247

51. Kossmann, J., Visser, R.G.F., Müller-Röber, B., Willmitzer, L., and Sonnewald, U. (1991) Mol. Gen. Genet. 230, 39-44

52. Thon, V.J., Vigneron-Lesens,C., Marianne-Pepin, T., Montreuil, J., Decq, A., Rachez, C., Ball, S.G., and Cannon, J.F. (1992) J.Biol.Chem. 267, 15224-15228

53. Inouchi, N., Glover, D.V., and Fuwa, H. (1987) Starch/Stärke 39, 259-266

54. Takeda, Y. and Preiss, J. (1993) Carbohydr. Res. 240, 265-275

55. Fuwa, H., Glover, D.V., Miyaura, K., Inouchi, N., Konishi, Y., and Sugimoto, Y. (1987) Starch/Stärke 39, 295-298

56. Fontaine, T., D’Hulst, C., Maddelein, M-L., Routier, F., Marianne-Pepin,T., Decq, A., Wieruszeski, J.M.,Delrue, B., Van Den Koornhuyse, N., Bossu, J-P.,Fournet, B., and Ball, S.G.(1993) J. Biol. Chem. 268, 16223-16230

57. Maddelein, M-L, Libessart, N., Bellanger, F., Delrue, B., D’Hulst, C., Van Den Koornhuyse, N., Fontaine, T., Wieruszeski, J.M., Decq, A. and Ball, S.G. (1994) J.Biol.Chem. 269, 25150-25157

58. Jenkins, P.J., and Donald, A.M. (1995) Int. J. Biol. Macromol. in press

59. Sumner, J. B., and Somers, G.F. (1944) Arch. Biochem. 4, 7-9

60. Erlander, S. (1958) Enzymologia 19, 273-283

61. Pan, D., and Nelson, O.E. (1984) Plant Physiol. 74, 324-328

62. Struhl, K. (1983) Nature 305, 391-397

Received on May 22, 1995, accepted on June 16,1995 